\title{
Appliance of Electron Beam Technology for Disinfection of Sewage Water to Minimize Public Health Risks.
}

By

Y. AVASN Maruthi ${ }^{1 *}$, N Lakshmana Das ${ }^{1}$, Kaizar Hossain ${ }^{1}$,

K. P. Rawat ${ }^{2}$, K. S. S. Sarma ${ }^{2}$ and S. Sabharwal ${ }^{2}$

\begin{abstract}
First time in India, a study was aimed to establish a base- line data for electron beam radiation dose level needed to disinfect and also improve the water quality of sewage water for possible reuse in irrigation, industries as well as a few domestic purposes. Raw and secondary treated sewage water samples, which were rich with microorganisms from Navi Mumbai municipal sewage plant were irradiated with electron beam accelerator at doses of $0.45,0.75,1.5,3.0,4.5,6.0,7.5,9.0$ and $10.5 \mathrm{kGy}$. Electron Beam irradiation treatment of the wastewater was found to be very effective in reducing the pathogenic load. Electron Beam (EB) dose of $1.5 \mathrm{kGy}$ was sufficient for complete elimination of total coli forms whereas Cryptococcus laurentii, Aspergillus fumigatus and Absidia sp. were killed by10.0 kGy and no larvae of helminthes (Ascaris lumbricoides) were recovered at the dose $\geq 1.5 \mathrm{kGy}$. The experimental findings obtained highlighted the potential of this technology for disinfection of wastewater.
\end{abstract}

Keywords: Electron beam irradiation, Disinfection \& Sewage water

\section{Introduction}

India faces a turbulent water future, unless water management practices are changed India will face a severe water crisis within the next two decades and will have neither the cash to build new infrastructure nor the water needed by its growing economy and rising population. Water is one of the critical inputs for the sustenance of mankind. Almost $70 \%$ of the water resources of India have been polluting due to the discharge of domestic sewage and industrial effluents into natural water source, such as rivers, streams as well as lakes [1]. About $95 \%$ of rural population living in India depends on ground water for domestic use and also for various activities [2].

Coliforms and Fungi are the prevalent in sewage rich environments. The waste water and sewage are rich in organic matter, are habitat for many microorganisms

a GITAM Institute of Science, GITAM University, Visakhapatnam-530045, Andhra Pradesh, India.

b Radiation Technology Development Division, Bhabha Atomic Research Centre (BARC), Mumbai-400085, India

*Corresponding Author 
[3] and domestic sewage is a rich source of human excreta, keratin, cellulose and lignin etc. where the occurrence of pathogenic microorganisms can be easily expected.

In general, the qualitative and quantitative composition of coliforms can be multifunctional bioindicator of environmental pollution with sewage. It means that the composition indicates not only the presence of faecal contaminants in the environment but also respond to the changes in environmental conditions. Additionally, the fungal growth informs us about the infection risk associated with the contamination of the environment with potential fungal pathogens [4]. Recently, application of ionizing irradiation, especially electron beam radiation that is generated from electron beam accelerator to treat sewage water has attracted the environmentalists. It was reported that ionizing radiation induces both the degradation of numerous compounds and the inactivation of microorganisms in sewage on irradiation, depending on the type of energy and dose rate $[5,6 \& 7]$.

Many disease-causing viruses, parasites, and bacteria also are present in wastewater and enter into community whenever possible. These pathogens often originate from people and animals that are infected with or are carriers of a disease. Graywater and blackwater from typical homes contain enough pathogens to pose a risk to public health. Other likely sources in communities include hospitals, schools, farms, and food processing plants. Some illnesses from wastewater-related sources are relatively common.

Sewage system has to be established to collect the waste material; however, providing sewers for the cities is not a complete solution of the problem of excreta disposal, because sewage disposal into water resources or land would actually lead to the spreading of intestinal diseases and other environmental hazards. The character and degree of wastewater treatment depend on the raw water whether it is from factories or residential, and also on the system used. If wastewater is to be used for irrigation of agriculture crops, in an instructed manner, including a high degree fruit and vegetables usually consumed uncooked, disinfection is necessary to inactivate the pathogens. Additional processes may be required to remove certain resistant protozoan or helminthes.

In water as well as wastewater, the principal component is water. Therefore, it would be expected that the effect of ionizing radiation might be dominated by interaction of radiation and water [8]. As far as pure water is concerned, when exposed to ionizing radiation, the radiolysis of water can be presented as following equation [9].

$$
\mathrm{H}_{2} \mathrm{O} \rightarrow[2.7] \mathrm{OH}^{*}+[2.6] \mathrm{e}_{\mathrm{aq}^{-}}+[0.6] \mathrm{H}^{*}+[2.6] \mathrm{H}_{3} \mathrm{O}^{+}+[0.7] \mathrm{H}_{2} \mathrm{O}_{2}+[0.45] \mathrm{H}_{2}
$$


So if we consider pure water, each $100 \mathrm{eV}$ absorbed by water will result in the generation of 2.7 radical $\mathrm{OH}^{*}, 2.6 \mathrm{e}_{\mathrm{aq}}{ }^{-}, 0.6$ radical $\mathrm{H}^{*}, 2.6 \mathrm{H}_{3} \mathrm{O}^{+}, 0.7$ molecule of $\mathrm{H}_{2} \mathrm{O}_{2}$ and 0.45 molecule of $\mathrm{H}_{2}[10]$.

Powerful oxidizing and reducing species (e.g., $\mathrm{OH}, \mathrm{e}_{\mathrm{aq}}{ }^{\mathrm{A}}, \mathrm{H}$ ) and molecular products (e.g., $\mathrm{H}_{2}, \mathrm{H}_{2} \mathrm{O}_{2}$ ) are produced due to the interaction between radiation and water, so these chain reactions lead to the phenomenon as described earlier by Parker and Darby (1995) Sommers and Glenn (2006) and Maruthi et.al (2011) $[11,12 \& 13]$.

The ionizing radiation affects with matter in two ways: directly and indirectly. In direct interaction, the ionizing radiation affects with critical molecules like DNA and proteins present in the microorganism causing cell death.

\section{$\mathrm{H}_{2} \mathbf{O} \rightarrow \mathrm{OH}^{*}, \mathrm{e}_{\mathrm{aq}}{ }^{-}, \mathrm{H}^{*}, \mathrm{H}_{2}, \mathrm{H}_{2} \mathbf{O}_{2}$}

$\mathbf{O H}^{*}, \mathbf{e}_{\mathrm{aq}}{ }^{-}, \mathbf{H}^{*}+$ DNA (in microorganism) $\rightarrow$ Damage to DNA

During indirect interaction, radiolysis products of water results in the formation of highly reactive intermediates which then react with the target biomolecules culminating in the cell death. Therefore, the effects of Electron beam irradiation on the inactivation of microorganisms, mainly on the pathogens present in sewage water were investigated.

The objective of this study was disinfection of sewage water using Electron Beam (EB) technology and also to prove that EB technology is a promising technology over conventional disinfection techniques. The EB treated sewage water can be effectively used in irrigation (agriculture fields and aesthetic purpose) as well as in industries as it does not contain any pathogens, on the other hand public health should be protected.

\section{Material and Methods}

For a comparative study, the water samples were collected from two different domestic sewage water treatment plants $(A \& B)$, Mumbai (inlet area from where raw sewage is entering into the plant and outlet i.e. prior to chlorination) those are employing conventional disinfection methods to disinfect sewage water. The samples were brought to the laboratory with the help of sterile plastic bottles kept them in ice boxes and analysed for total microbial count by adopting standard procedures [14].

\subsection{Irradiation of sewage water}

A laboratory scale study was carried out regarding the possibility of electron beam application for sewage water disinfection. To carry out the experiment the stainless steel belt conveyor was constructed for irradiation under continues flowing condition. The width and depth of water container was designed to $60 \mathrm{~cm}$ and $0.7 \mathrm{~cm}$ respectively, which was fit to the penetration range of experimental accelerator. The rate of sewage water moving through conveyor 
belt was controlled in $\sim 3000 \mathrm{cc} / \mathrm{min}$, which treat up to $1.5 \mathrm{~m}^{3} / \mathrm{hr}$. The radiation experiment was carried using ILU-6 Accelerator (ILU-6 pulse Accelerator parameters are shown in table-1), at Electron Beam Facility of the Radiation Technology Development Division of the Bhabha Atomic Research Centre, Mumbai, India. Then all samples were analysed for same parameters after EB treatment at different doses $(0.45 \mathrm{kGy}, 0.75 \mathrm{kGy}, 1.5 \mathrm{kGy}, 3 \mathrm{kGy}, 4.5 \mathrm{kGy}$, $6 \mathrm{kGy}, 7.5 \mathrm{kGy}, 9 \mathrm{kGy} \& 10 \mathrm{kGy})$ at room temperature.

Table -1 ILU-6 pulse Accelerator parameters during the experiment

\begin{tabular}{|l|l|}
\hline Energy & $2 \mathrm{MeV}$ \\
\hline Average Beam Current & $1.2 \mathrm{~mA}$ \\
\hline Pulse repetition frequency & $10 \mathrm{~Hz}$ \\
\hline Conveyor Speed & $\sim 10 \mathrm{~cm} / \mathrm{sec}$ \\
\hline Pulse current & $250 \mathrm{~mA}$ \\
\hline Pulse accelerator duration & $\sim 500 \mu \mathrm{S}$ \\
\hline
\end{tabular}

The dosimetry study was carried out by using FWT60 radio chromic films calibrated by Graphite Calorimeter.

\section{Microbial count}

Plate count method was used to enumerate the microbial count. The HiMedia Plate count Agar (M091-500G) was used for Total bacterial Count, HiMedia MacConkey Agar (M081A) for coliforms and Hi-Media SalmonellaShigella Agar (M108) for Total Salmonella-Shigella were used. The wastewater samples were diluted in Phosphate buffer (Hi-Media M 461) and were used on spread plate method on agar, then incubated at $37^{\circ} \mathrm{C}$ until Colony formation was observed. Potato dextrose agar (PDA) was used for fungi culturing and immediately after irradiation morphological and developmental status of eggs was examined microscopically [15]. These eggs were incubated for 8 weeks. From the resulted growth were observed by their colonial morphology, stained with Lacto phenol Cotton blue dye and photographed by using Binocular Digital Research Microscope (from Labomed, USA) and analyzed by using a software Progres Capture Pro. The microphotographs were identified by comparing with available literature.

\section{Results and Discussion}

The effect of electron beam radiation on pathogenic microorganisms in sewage water were evaluated as a function of absorbed dose by determining the change of microbial load as shown in fig. 1-8 and table No.2 


\subsection{E B treatment is substitute for Chlorine disinfection}

Presence of oxygen is important in the process as the oxygen is a known radiosensitizer which helps in fixing the radiation damage done to cells thereby inhibiting theirself repair mechanism and resulting in inactivation of the microorganism [16]. As a result, small molecules may be broken into shorter chains and/or so activated that the potential for chemical reactions is increased. In the connection the electron also produce ozone, peroxide, hydroxide ions, and oxygen ions in even pure water. These products of irradiation are very strong oxidants due to ionization and absorption of energy into the molecular chain structure and breaking molecular structures [17].

Samples were obtained from the treatment plant to examine the inactivation of microorganisms with radiation technology and shown the inactivation of total and faecal coliforms (organisms per $\mathrm{ml}$ ) in the raw inlet and unchlorinated outlet water samples. Our study observed that total pathogenic microorganisms were reduced to below detection limit.

In case of treatment plant-A, inlet sewage water sample, total bacterial count, total coliforms, total Salmonella-Shigella, Cryptococcus laurentii, Aspergillus fumigatus, Absidia sp and Ascaris lumbricoides were reduced from $6.1 \times 10^{5}$ to 0 at $3.0 \mathrm{kGy}, 9.6 \times 10^{4}$ to 3 at $0.75 \mathrm{kGy}, 4 \times 10^{3}$ to 0 at $0.75 \mathrm{kGy}$, $1.2 \times 10^{3}$ to 0 at $9 \mathrm{kGy}, 0.9 \times 10^{3}$ to 0 at $10 \mathrm{kGy}, 0.6 \times 10^{3}$ to 0 at $10 \mathrm{kGy}$ and 0.5 $\times 10$ to 0 at $1.5 \mathrm{kGy}$ respectively where as outlet, total bacterial count, total coliforms, total Salmonella-Shigella, Cryptococcus laurentii, Aspergillus fumigatus, Absidia sp and Ascaris lumbricoides were reduced from 4.8× $10^{4}$ to 0 at $3.0 \mathrm{kGy}, 1.6 \times 10^{4}$ to 1 at $1.5 \mathrm{kGy}, 5 \times 10^{3}$ to 0 at $0.75 \mathrm{kGy}$ (Fig.1\&2), 3.7 $\times 10^{3}$ to 0 at $10 \mathrm{kGy}, 3.8 \times 10^{3}$ at $10 \mathrm{kGy}, 5.1 \times 10^{2}$ to 0 and $5.1 \times 10$ to 0 at 1.5 kGy (fig-1-8). Similarly for treatment plant-B, inlet total bacterial count, total coliforms, total Salmonella-Shigella, Cryptococcus laurentii, Aspergillus fumigatus, Absidia sp and Ascaris lumbricoides were reduced from reduced from $6.8 \times 10^{5}$ to 0 at $3.0 \mathrm{kGy}, 10.6 \times 10^{4}$ to 36 at $0.75 \mathrm{kGy} 1.4 \times 10^{4}$ to 23 at 0.75 $\mathrm{kGy}, 1.7 \times 10^{3}$ to 0 at $10 \mathrm{kGy}, 0.8 \times 10^{3}$ to 0 at $10 \mathrm{kGy}, 1.2 \times 10^{2}$ to 0 by $10.0 \mathrm{kGy}$ and $0.4 \times 10$ to 0 at $1.5 \mathrm{kGy}$ (fig-1-8) and in outlet sewage total bacterial count, total coliforms, total Salmonella-Shigella, Cryptococcus laurentii, Aspergillus fumigatus, Absidia sp and Ascaris lumbricoides were reduced from $5.2 \times 10^{4}$ to 0 at $3.0 \mathrm{kGy}, 1.9 \times 10^{4}$ to 1 at $1.5 \mathrm{kGy} 5.4 \times 10^{3}$ to 13 at $0.75 \mathrm{kGy}, 1.7 \times 10^{3}$ to 0 at $9 \mathrm{kGy}, 0.8 \times 10^{3}$ to 0 at $9 \mathrm{kGy}, 1.2 \times 10^{2}$ to 0 by 10.0 $\mathrm{kGy}$ and $0.4 \times 10^{2}$ to 0 by $3 \mathrm{kGy}$ (fig-1-8). In the present study ova of helminthes were found in raw sewage (Ascaris lumbricoides). The mean number of this species ranges between 45-80 eggs per liter. The eggs were incubated for 8 weeks after this period no larvae were observed and it was shown the efficiency of 
radiation treatment to destroy $\boldsymbol{A s c a r i s}$ ova viability and found that no ova were viable after exposure to $0.75 \mathrm{KGy}\left(\mathrm{D}_{10}\right.$ at 0.45$)$.

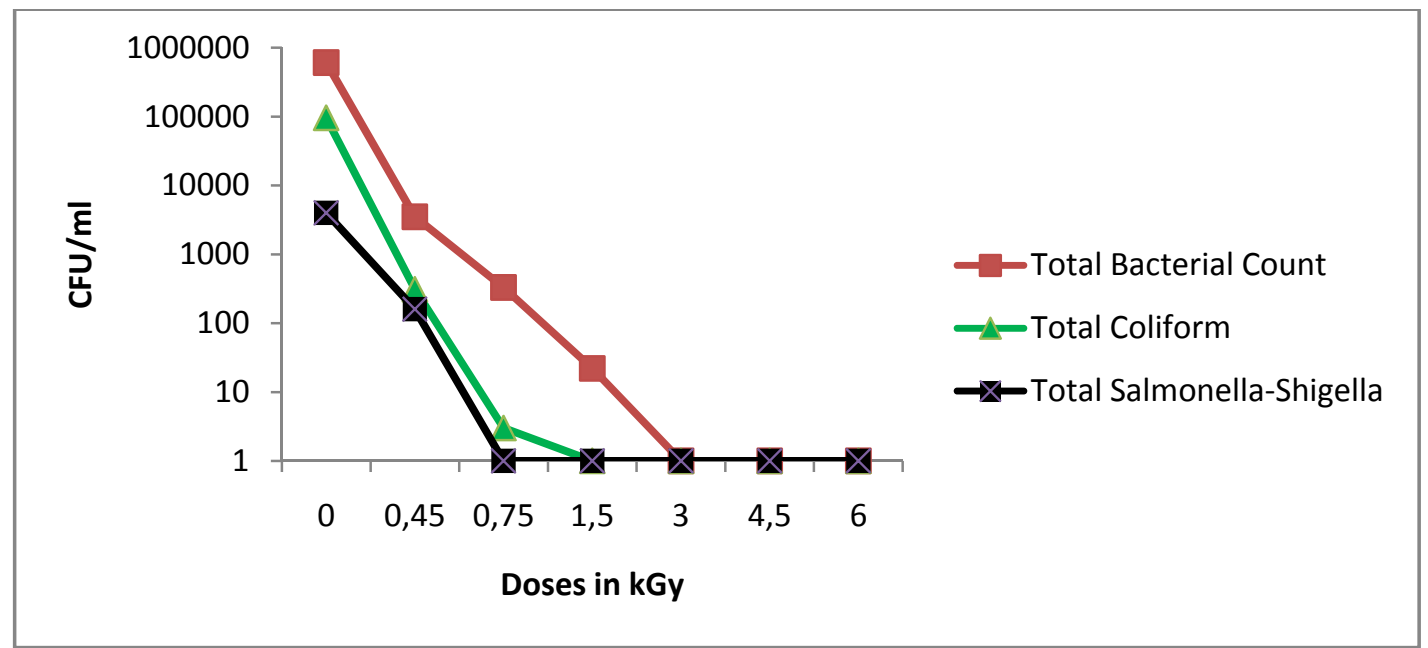

Figure 1 Effect of E B radiation on sewage bacteria (treatment plant-A, Inlet Sample)

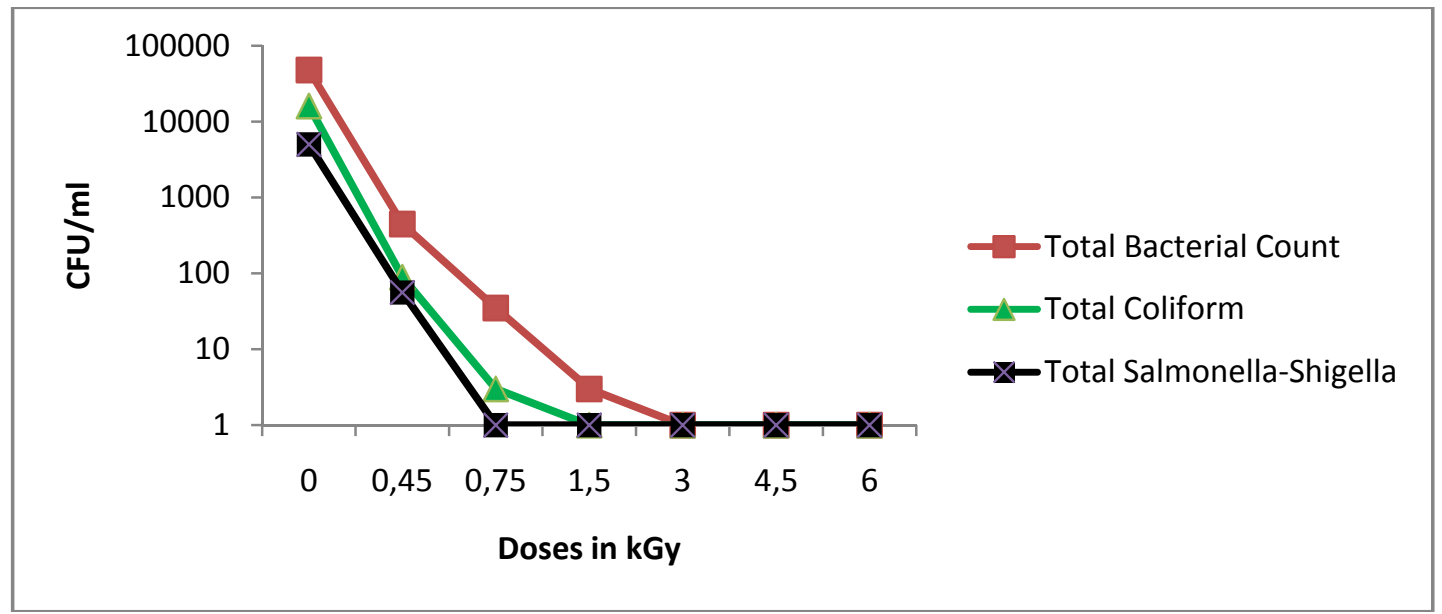

Figure 2 Effect of E B radiation on sewage bacteria (treatment plant-A, Treated sewage Sample of outlet before chlorination) 


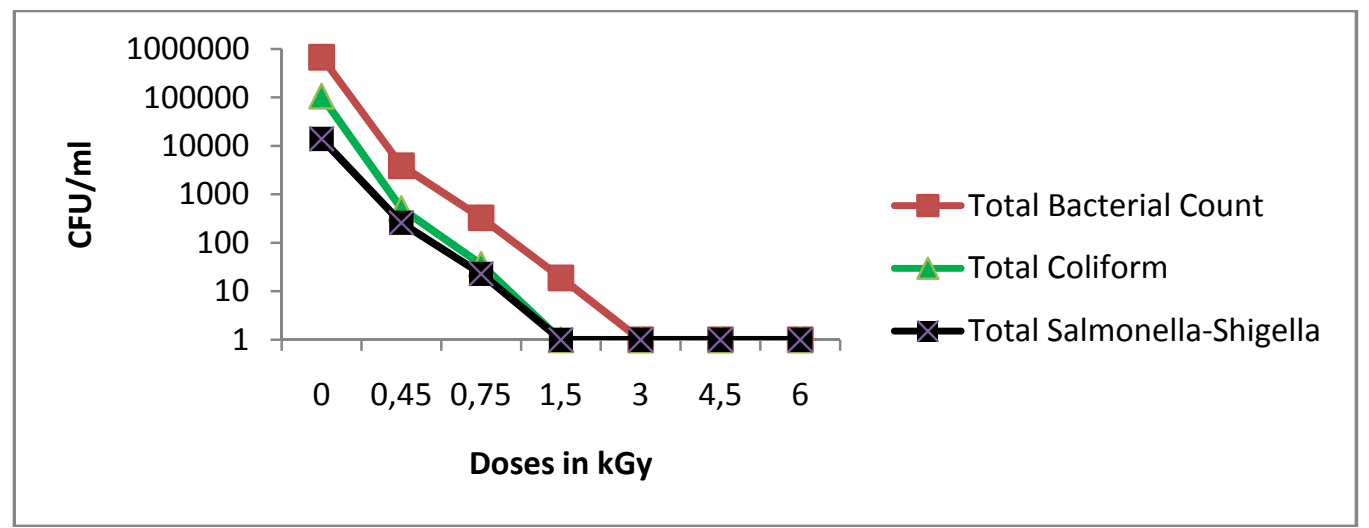

Figure 3 Effect of E B radiation on sewage bacteria (treatment plant-B, Inlet Sample)

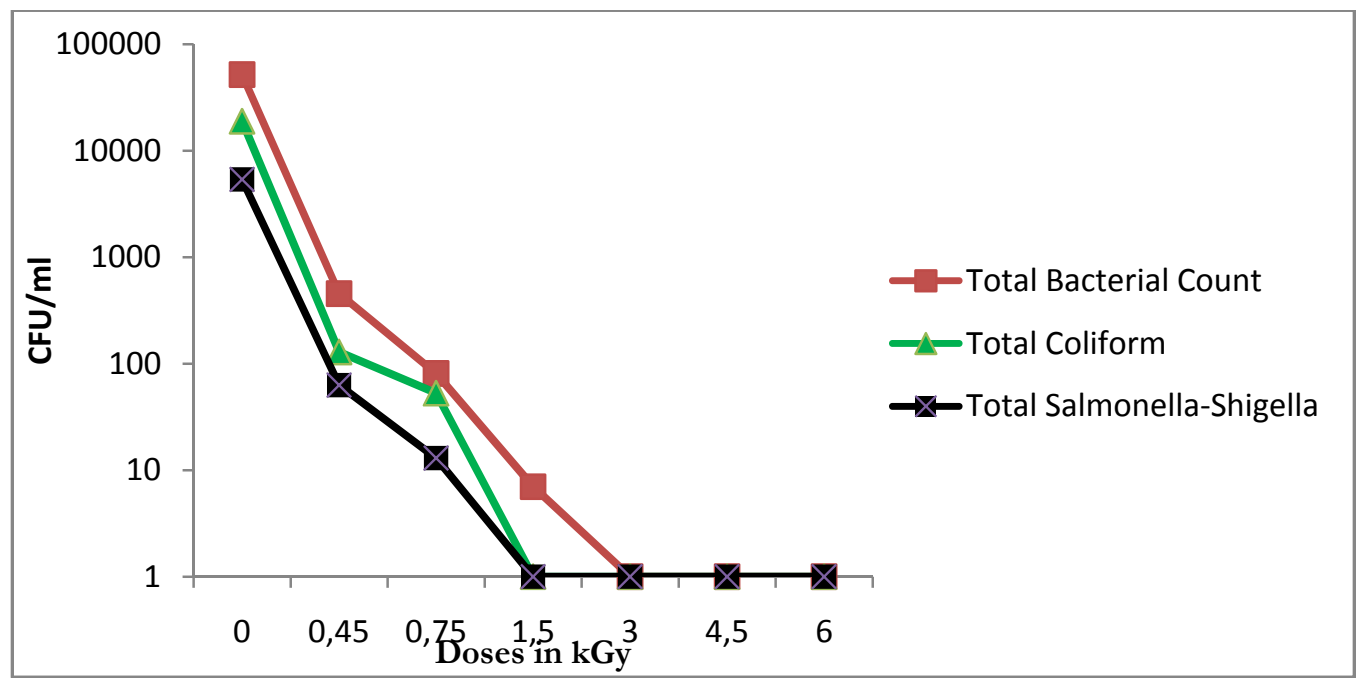

Figure 4 Effect of E B radiation on sewage bacteria (treatment plant-B, Treated sewage Sample of outlet before chlorination)

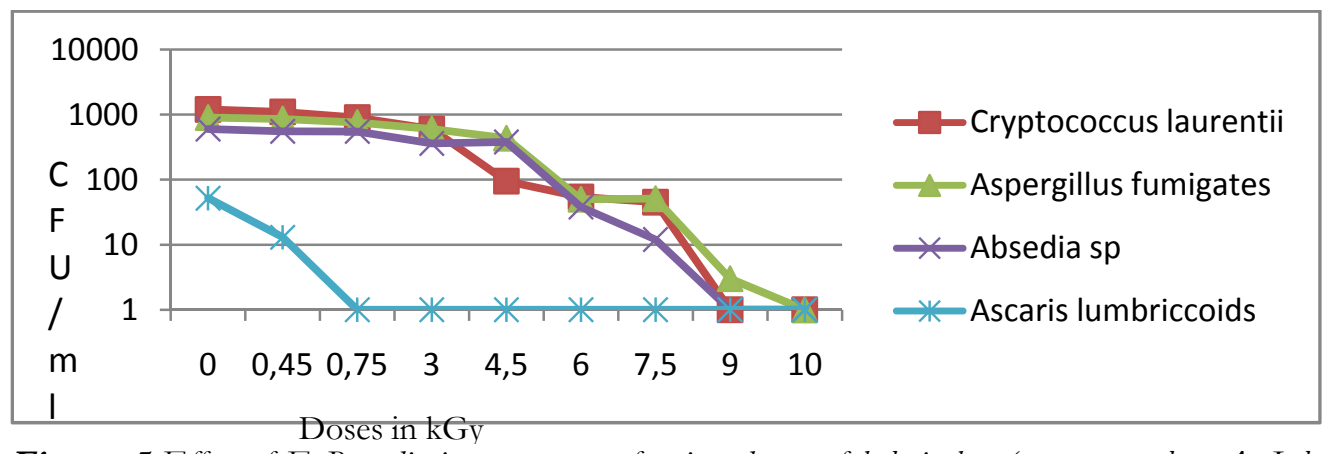

Figure 5 Effect of $E$ B radiation on sewage fungi and ova of helminthes (treatment plant- $\boldsymbol{A}$, Inlet Sewage Sample) 


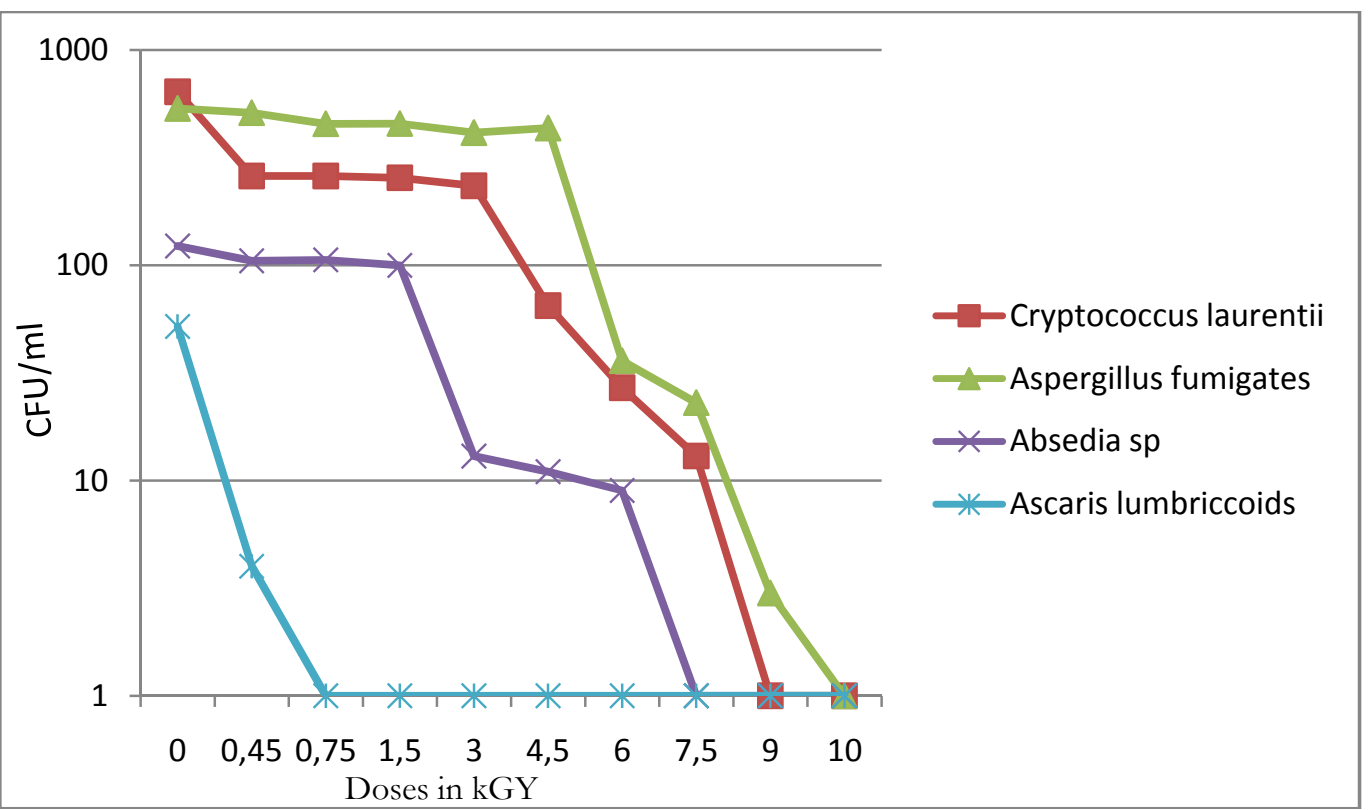

Figure 6 Effect of $E$ B radiation on sewage fungi and ova of helminthes (treatment plant-A, Treated sewage sample of outlet before Chlorination)

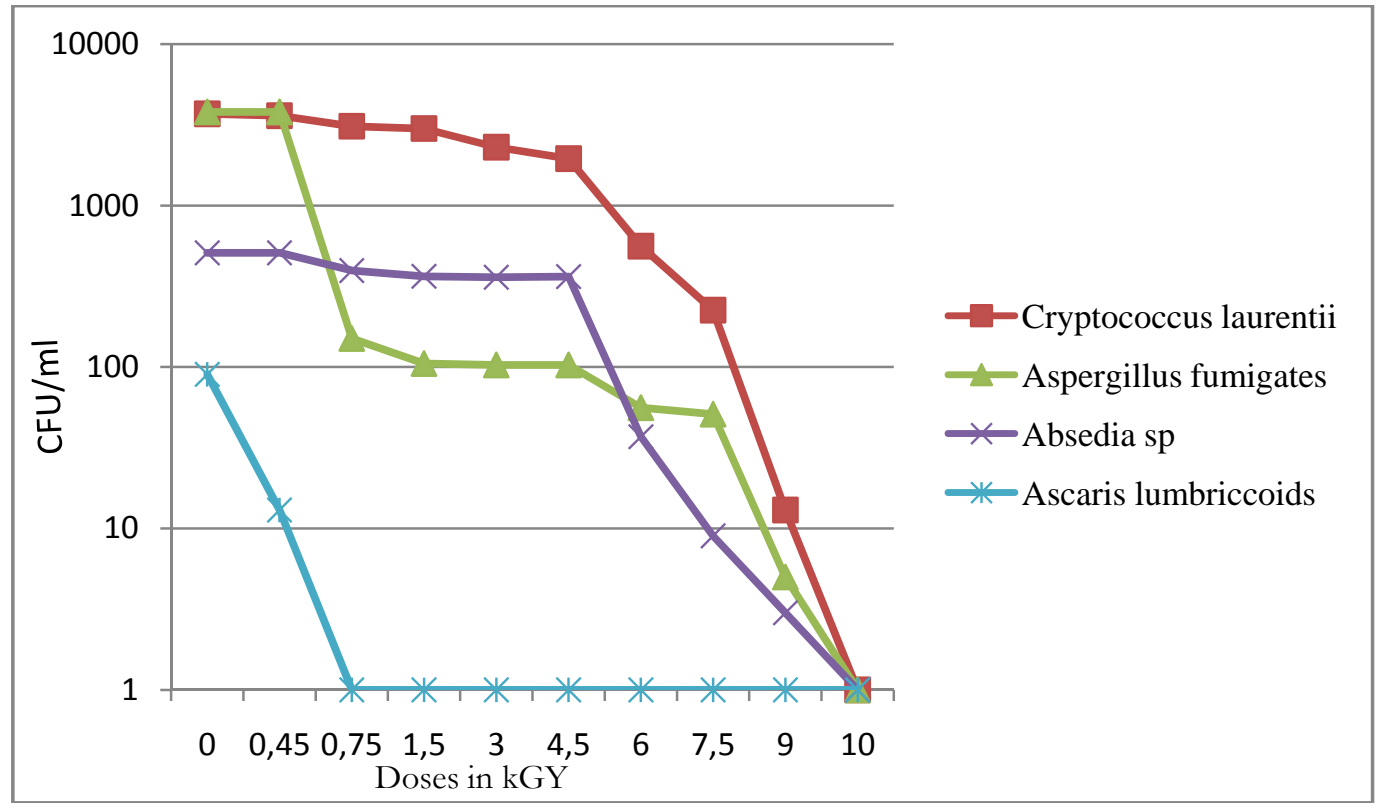

Figure 7 Effect of E B radiation on sewage fungi and ova of helminthes (treatment plant-B, Inlet Sewage Sample) 


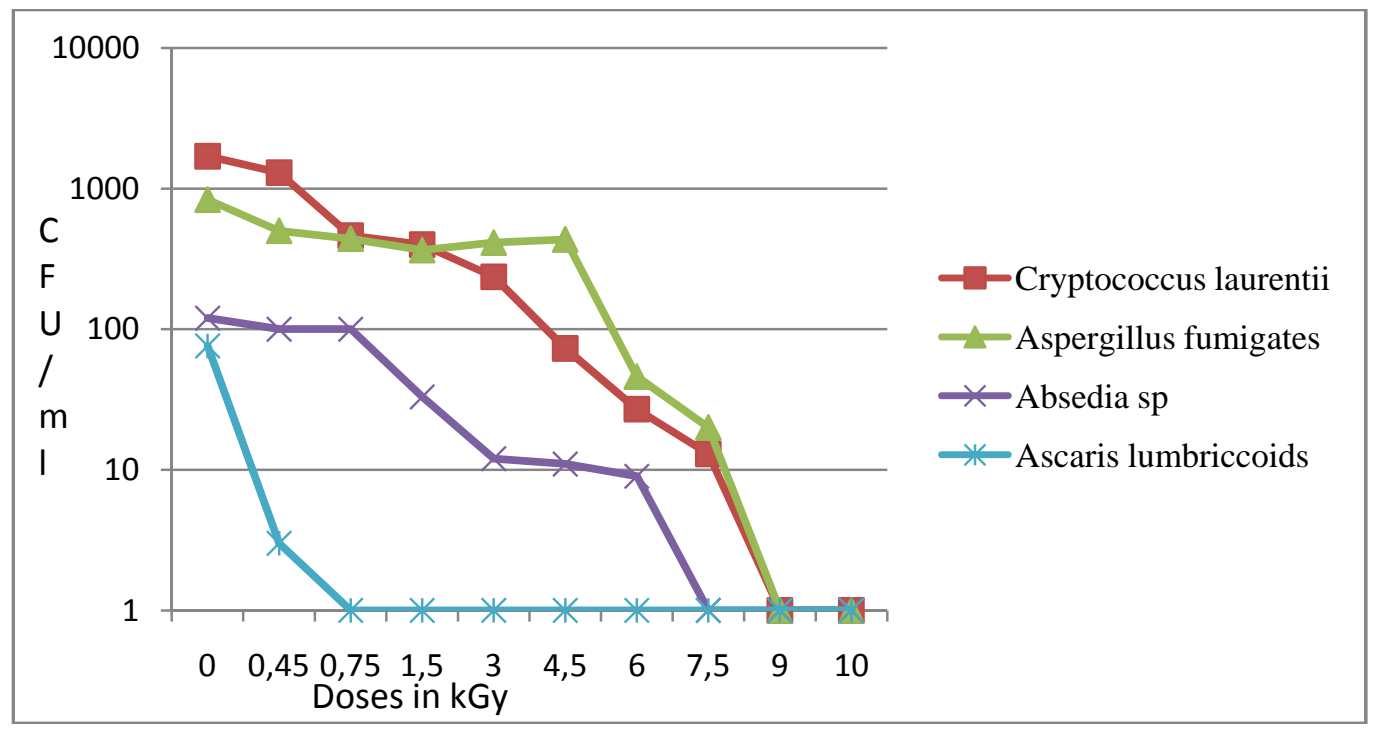

Figure $\boldsymbol{8}$ Effect of $E \mathrm{~B}$ radiation on sewage fungi and ova of helminthes (treatment plant-B, Treated sewage sample of outlet before chlorination)

The gross appreciation of radiation effects on microorganisms is made by the way of two main parameters. A) The lethal dose for which the whole of microorganisms is killed or inactivated. B) The $\mathrm{D}_{10}$ Value that corresponds to the dose for which the number of viable microorganisms presents in the initial medium is decreased by $1 \log$. The radiation dose required to inactivate the pathogenic bacteria is generally defined in terms of the $D_{10}$ value, which is the radiation dose required to reduce (through inactivation or cell death) the microbial concentration by a factor of ten or by one log cycle. This principle was the basis for producing radiation sterilized, single use medical products and is now well established in industry worldwide [18]. Based on the same principle, the pathogens present in sewage water can be also effectively removed by exposure to high energy radiation. In this study EB treatment was found to be very effective in reducing the bacterial count, especially total coliforms count to a safe level and the $\mathrm{D}_{10}$ values of the Total Bacterial Count, Total Coliforms, Total Salmonella-Shigella and Ascaris lumbricoides was found to be $\leq 0.4 \mathrm{kGy}$ (Table-2) and $1.5 \mathrm{kGy}$ was sufficient for $5 \log$ elimination of total coli forms. (As shown Fig.-1-4) The effectiveness of gamma and EB in eliminating bacterial load was also reported by Basfar et al (2002) \& Rawat et al (1998) [19 \& 20], for Cryptococcus laurentii is was $\leq 0.4 \mathrm{kGy}$, Aspergillus fumigatus and Absidia sp $\leq 6 \mathrm{kGy}$ was In the present study ova of helminthes were found in raw sewage (Ascaris lumbricoides). The irradiation was made and the effect of the radiation detected compared to the control after incubation and no larvae were recovered at dose >1.0 KGy. Capizza, el al (1999) [21] found life larvae in the rate 
of radiation below $0.75 \mathrm{KGy}$. Ascaris lumbricoides is a warm that causes infection, in man all over the world. Millions of people are annually reported as infected. The infection causes heavy losses in resources and mortalities [22].

Table -2. $\mathbf{D}_{10}$ Value for test microorganisms.

\begin{tabular}{|l|l|l|}
\hline S.No & Organisms & $\mathbf{D}_{10}$ Value \\
\hline 1 & Total Bacterial Count & $\leq 0.45$ \\
\hline 2 & Total Coliforms & $\leq 0.45$ \\
\hline 3 & Total Salmonella- Shigella & $\leq 0.45$ \\
\hline 4 & Cryptococus laurentii & $\leq 4.5$ \\
\hline 5 & Aspergillus fumigates & $\leq 6$ \\
\hline 6 & Absidia sp & $\leq 6$ \\
\hline 7 & Ascaris lumbriccoides & $\leq 0.45$ \\
\hline
\end{tabular}

\subsection{Economic feasibility of e- beam over conventional sewage water treatment methods}

Table-3. Cost estimation of conventional and radiation based technology for sewage water treatment. (US $\left.\$ / \mathrm{m}^{3}\right)$.

\begin{tabular}{|l|l|l|l|l|}
\hline $\mathrm{m}^{3} /$ day & Electron Beam & Ozone & UV & Chlorine \\
\hline 10,000 & 0.29 & 0.25 & 0.17 & 0.013 \\
\hline 50,000 & 0.073 & 0.086 & 0.171 & 0.013 \\
\hline 100,000 & 0.050 & 0.064 & 0.054 & 0.013 \\
\hline 200,000 & 0.041 & 0.053 & 0.047 & 0.013 \\
\hline
\end{tabular}

(US \$ / m3 Total cost including operation, capacity and discharge water).

The conventional treatment for sewage sludge involves stabilization by aeration or digestion (at about $35^{\circ} \mathrm{C}$ ) to reduce the numbers of pathogens, especially of bacteria such as salmonellae by 1 or $2 \log$ units. To obtain a safe hygienic sludge, further reduction of pathogens by about $3 \log$ units is necessary.

Disinfection by chlorination can be problematic, under some circumstances. Chlorine can react with naturally occurring organic compounds found in the water supply to produce compounds known as disinfection byproducts (DBPs). The most common DBPs are trihalomethanes (THMs) and haloacetic acids (HAAs). Due to the potential carcinogenicity of these compounds, drinking water regulations across the developed world require regular monitoring of the concentration of these compounds in the distribution systems of municipal water systems. The World Health Organization has stated that the "Risks to health from DBPs are extremely small in comparison with inadequate disinfection.

The design of waste water treatment plant is usually based on the need to reduce organic loads to limit pollution of the environment. Pathogen removal has very rarely been considered and observed but for reuse of effluents in agriculture, this must be of primary concern. Treatment to removal waste water constituents that may be toxic or harmful to crops, aquatic plants and fish is normally not 
economically feasible. However, the removal of toxic elements and pathogens that may affect human health need to be considered [23]. Even though our present study is costly, The EB treated sewage water can be effectively used in irrigation as well as in industries as it does not contain any pathogens. (Table-3) [13].

\section{Conclusions:}

According to the tendency of searching for cleaner alternative methodologies, the seed treatment technology using ionizing radiation produced by electron accelerators (electron beam- EB) presents as an environmental friendly alternative without the use of chemicals. In conventional method, the chlorination of water results in the formation of toxic organo-chlorine products, which are mutagenic and carcinogenic in nature. This study accentuates implementation of electron beam technology for sewage water disinfection for developing countries to combat against water scarcity.

\section{Acknowledgments}

This work was funded by the DAE (Department of Atomic Energy), BRNS (Board of Research on Nuclear Sciences, BARC (Bhabha Atomic Research Centre), India. So we are giving thanks to DAE, BRNS, BARC and GITAM University for utilising facilities. We (First three authors) would like extend our sincere thanks to Sri. S A Khader Scientific Officer D, ILU-6 Electron Beam Facility of the Radiation Technology Development Division of the Bhabha Atomic Research Centre, Mumbai., India, for the constant guidance and all the possible help during the irradiation of sewage samples.

\section{References}

Sangu, S. K and. Sharma, R.P.S. 1987. An assessment of water quality of river Ganga at Garmukteshwar (Ghaziabad). Ind J. Ecol., 14(2) 278-287.

Moharir, D.S., Ramteke, C.A Moghe, S.R Wate and Sarin, R. 2002. Surface and ground water quality assessment in Bina region. Ind.Journal of Environ.Protec. 22(9), 960-969.

Kacprzak, M. Neczaj, E. and Okoniewska, E 2005. The comparative mycological analysis of waste water and sewage sludges from selected waste water treatment plants. Desalination. 185(13), 363-370

Krzysztof Ulfig 2000 The occurrence of Keratinolytic Fungi in waste and waste-contaminated habitats. Revista Iberoamericana de Micologia. 44-50.

Klieber, N. Bagnato, R. Barrett and Sedgley, M. 2002. Effect of post-ripening nitrogen atmosphere storage on banana shelf life, visual appearance and aroma. Postharvest Biol Technol 25, 15-24 
Drzewicz, P and Gehringer, P. 2005. The radiolytic degradation of the widely used herbicide dicamba (3,6-dichloro-2-methoxybenzoic acid), employing gamma irradiation in laboratory batch conditions and with a beam of accelerated electrons in flow-through installation. Arch Environ Contam Toxicol 48, 311-322.

Casimiro, M. H. Leal, J. P. Gil, M. H. and Botelho, M. L. 2008 Gamma radiation induced effects on slaughterhouse wastewater treatment. Radiat. Phys. Chem, 77, 98-100

Daniel E. Meeroff, D. Thomas, P. E. Waite, M. ASCE. Junko Kazumi and Kurucz Charles, N. 2004. Radiation-Assisted Process Enhancement in Wastewater Treatment. J Envir Engrg 130(2), 155-166.

Spinks, J.W. T. Woods, R. J. 1990 An Introduction to Radiation Chemistry, Third Edition, JohnWiley and Sons, Inc., New York, pp. 45.

Borrely, S. I. Cruz, A. C. Delmaestro, N. L. Sampa M. H. O and Somessari, E. S. 1998 Radiation processing of sewage sludge: a review. Prog. Nul. Energy 33, 3-21

Parker, A. and Darby, J. L. 1995. Particle-associated coliform in secondary effluents: Shielding from ultraviolet light disinfection. Water Environ. Res 67: 1065-1075

Sommers, H. and Glenn, B. 2006. Variations in the radiation sensitivity of foodborne pathogens associated with complex ready-to-eat food products. Radiat Phys Chem 75, 773-778

Maruthi, AVASN Y, Lakshmana Das, N. Kaizar Hossain, Sarma, K S S Rawat, K. P. and Sabarwal, S. 2011. Disinfection and reduction of organic load of sewage water by electron beam radiation. Applied water science. 1, 49-56

American Public Health Association (APHA) 2005. Standard Methods for the Examination of Water and wastewater. 2th Edition.

Priya Moodley, Colleen Archer and David Hawksworth. 2008. Standards methods for the Recovery and enumeration of helminth ova in Wastewater, sludge, compost and Urinediversion waste in south Africa, WRC Report No. TT322/08

Pikaev, A.K. 1997. Current status of radiation treatment of water and wastewater Sewage and wastewater for u se in agriculture, IAEA TECDOC-971: pp. 183-190.

Rihab Moawia Ali Musaad, Disinfection of Sewage Water and Sludge using Gamma Radiation. Ph.D. thesis diss., Sudan Academy of Science, 2002.

Pikaev, K. Woods, R. J. 1994. Applied Radiation Chemistry: Radiation Processing, John Wiley and Sons Inc., New York, pp. 535

Basfar, A. and Abdel Rehim, F. 2002. Disinfection of wastewater from a Riyadh Waste water Treatment Plant with ionizing radiation. Radiat. Phys. Chem 65, 527-532.

Rawat, K. P. Sharma, A. Rao, S. M. 1998. Microbiological and physio chemical analysis of Radiation disinfected municipal Sewage. Water Res 32(3), 737-740.

Capizzi, S. Chevalleir, A. Schwartzbrod, J. 1998. Destruction of Ascaris ova by accelerated electron. Radial Phys and chem 56, 591-595.

World health organization 1989. Health guidelines for the use of wastewater in agriculture and aquaculture Geneva, Switzerland: World Health Organization. Technical Report Series: pp. 778.

Pereira, L. S. Cordery, I. Iacovides, I. 2002 Coping with water scarcity. UNESCO IHP VI, Technical Documents in Hydrology 58. UNSCO, Paris, pp. 267. 